\title{
SHIFTING POSITIONS ON HOPE VALUE
}

\author{
Chris Grzesik, FRICS REV \\ The European Group of Valuers' Associations \\ e-mail: chrisg@polishproperties.com.pl
}

Sabina Źróbek, prof.

University of Warmia and Mazury in Olsztyn

Department of Real Estate Management and Regional Development

e-mail: zrobek@uwm.edu.pl

\begin{abstract}
The aim of this article is to shed some light on the difficulty, and at the same time, the unavoidable change towards the embracing by valuers in Poland, of one of the most fundamental principles of property valuation, being "highest and best use" and "hope value". Both are inherently linked to the interpretation of "market value". The article offers a detailed analysis of international practice and the most important developments concerning professional standards for property valuers in Poland. The considerations presented herein focus mostly on issues arising out of the interpretation of "market value". While the legal wording of its Polish definition could be considered similar to the one presented in internationally recognised valuation standards, Polish practice concerning assumptions about the use of a property at the date of valuation is very different.
\end{abstract}

Key words: Market value, highest and best use, hope value, real estate.

JEL Classification: R30

Citation: Grzesik C., Źróbek R., 2017, Shifting Positions on Hope Value, Real Estate Management and Valuation, vol. 25, no. 3, pp. 23-29.

DOI: $10.1515 /$ remav-2017-0019

\section{Introduction}

The concept of the highest and best use of property is always mentioned in professional standards and literature whenever the determination of a property's market value is discussed. It has been emphasised for many years that the need for the proper interpretation of this concept is of vital importance. Thus, such interpretation should be made before any specific valuation method is used (LANNHOFF, Elgie 1995; FinCH, CASAVANT 1996; SCRIBNER JR 1997; RATTERMANN et al. 2014). Many specialists have also highlighted the fact that the use of real property is not always clearly defined and this necessitates undertaking specific analysis before it can be determined. Such analysis should be based on valuation rules derived from economics, from the characteristics of the property in question and the environment in which it is located (KUCHARSKA-STASIAK, ŹRÓBEK, 2015; ŹRÓBEK et al. 2016).

The authors of this article have focused on presenting current opinions on how the use of real property is perceived in the context of property valuation in international markets, and on the evolution of the opinions of Polish property valuers. It is a significant element of the discussion in so far as valuers are the ones who should deliberately and skilfully apply the said rules and principles when preparing valuation reports. It should also be remembered that Poland has a highly institutionalised real property valuation system and this does not make it any easier to implement changes into the valuation practice. The authors raise the need to distinguish between the concepts of highest and best use and hope value and present a detailed interpretation of these two concepts with reference to the evolutionary changes in Polish valuation standards (Section 2). Section 3 presents the 
circumstances giving rise to Polish principles of valuation and professional standards including the bases of valuation. Section 4 refers to some provisions of Polish law and court decisions in connection with the interpretation of the nature of the use class of the property. Section 5 closes the article with conclusions and recommendations arising out of the authors' findings.

\section{Does the Highest and Best Use of a Property Include Hope Value?}

In recent years there has been much discussion at valuation seminars and conferences about the concepts of Hope Value. There has also been some misunderstanding amongst practitioners and academics alike about its true meaning and its connection with another often widely misunderstood valuation assumption, that of Highest and Best Use. Unfortunately shifting positions amongst the internationally recognised standard setting bodies (IVSC 1 , TEGoVA ${ }^{2}$ and RICS) has contributed to some of the confusion (GRZESIK 2014a).

Hope Value is not a new concept (GRZESIK 2014b) particularly in the United Kingdom where it is well understood given the specific nature of the country's planning system which often leaves developers at the mercy of local authority planners. Where planning consent for a proposed development is absent, at the date of valuation, the market value will reflect the additional value arising out of the hope that such consent will be forthcoming in the future, the amount of such "hope value" being dependent on the market's perception of the likelihood of such planning consent being granted.

Hope Value is often mistaken for a value in the future, which it is not. It is always a part of the market value of the property at the date of valuation. Furthermore it is not the value reflecting in full, the benefit of the desired planning or building consent. Rather it is an element of value which until the publication of IVS 2017, was considered as lying somewhere between the so called "Highest and Best Use" value of a property at the date of valuation and the value assuming that an even more valuable use which whilst at the date of valuation was not legally permissible was assumed to have become so.

The actual amount of hope value would have depended on the respective negotiating strength of the parties to the transaction as well as to the extent of the perceived likelihood of planning consent for the desired development becoming reality and the expected length of time of a positive planning decision being made.To understand this fully, one needs to examine what is meant by "Highest and Best Use".

\subsection{Highest and Best Use}

TEGoVA's 2009 edition of European Valuation Standards stated that Market Value is "... in principle based on the highest and best use of the property" defined as "The most probable use of the property which is physically possible, appropriately justified, legally permissible, financially feasible, and which results in the highest value of the property being valued". The latter definition was taken from IVS 2007 (8th Edition) published by the IVSC.

The words "legally permissible" gave rise to most of the problems with interpretation. In particular, valuers in countries with local master plans and formal zoning systems became uncertain about the assumption to be made about the value, of a use which whilst not legally permissible through lack of zoning, at the date of valuation, was likely to be become legally permissible sometime in the future. For example in the case of a site suitable for office development but zoned residential, or land zoned agricultural but suitable for warehousing or retail development.

Basic American literature on real estate valuation (The appraisal... 2013) indicates that market value can be assessed under the highest and best use concept reflecting a future change of use (eg to a use in accordance with a future local master plan) in so far as the valuer is able to ascertain if and when such change of the plan will take place as well as the demand for such a change of use.

Whilst at the time, the concept of Highest and Best Use was considered fundamental to the interpretation of the definition of Market Value, the RICS in its own "Red Book" - "RICS Valuation Standards - Global 2011 (7th Edition)" made no reference to it. Instead it stuck to the familiar British Hope Value concept whilst avoiding American highest and best use terminology, as exemplified by the passage below concerning the exclusion of special value when assessing market value.

\footnotetext{
1 International Valuation Standards Council

2 The European Group of Valuers' Associations
} 
"... where the price offered by prospective buyers generally in the market would reflect an expectation of a change in the circumstances of the property in the future, this element of 'hope value' is reflected in Market Value. Examples of where the hope of additional value being created or obtained in the future may impact on the Market Value include: the prospect of development where there is no current permission for that development; and the prospect of synergistic value arising from merger with another property or interests within the same property at a future date

Subsequently TEGoVA in its $7^{\text {th }}$ edition of EVS published in 2012 had moved away from its previous position of endorsing the concept of Highest and Best Use in favour a less restrictive interpretation of the definition of market value which could reflect "hope value". Such position has remained unchanged in the latest $8^{\text {th }}$ edition of EVS published in 2016 (EVS 2016).

\subsection{Hope Value}

EVS 2016 considers that the market value of a property reflects its full potential in so far as it is recognised by the market place. As stated in paragraph 5.3.4 "... it may reflect any "hope value" that the market may place on such prospects and as such, should be distinguished from an assessment of market value limited by the "highest and best use" assumption."

EVS 2016 paragraph 5.3.5 continues:"Hope value is used to describe an uplift in value which the market is willing to pay in the hope of a higher value use or development opportunity being achievable than is currently permitted under development control, existing infrastructure constraints or other limitations currently in place. It is an element within the Market Value of the property being considered... It will reflect an appraisal of the probability that the market places on that higher value use or development being achieved, the costs likely to be incurred in doing so, the time scale and any other associated factors in bringing it about. Fundamentally, it will allow for the possibility that the envisaged use may not be achieved. While descriptive of that uplift, it does not exist as a separate value but helps explain the Market Value of the property which must be judged from the available evidence just as much as any other part of the valuation. Hope value is not a special value as it represents the market place's reasonable expectations as to the opportunities offered by the property".

On highest and best use EVS 2016 at paragraph 5.3.7 states:"The concept of 'highest and best use' is met in a number of countries and some valuers in Europe may be asked to value a property on the assumption of its highest and best use. In essence that is the use that is actually permitted as at the date of valuation that offers the highest value. On analysis of the limitations intended to be imposed by its more formal definitions ... that excludes the hope value that the market might place on a property's potential opportunities that are not currently available. While finding the "highest and best use" of a property is an assessment of the property as it is on the date of valuation, it is not an assessment of the best use that the market might at that date reasonably envisage could be possible for it. This approach is thus Market Value limited by an assumption and not a simple Market Value or an element within Market Value".

As already mentioned above, the RICS in its 2011 Global Edition of the Red Book made no reference at all to Highest and Best Use. Indeed it had never mentioned the concept in its succession of 'Red Books' since the 1970s. That all changed with the publication of the 2014 edition of the Red Book which now included several references to "highest and best use". At the same time, whilst there was no longer any mention of "hope value", VPS 4 paragraph 1.2.7 provided that "...where the price offered by prospective buyers generally in the market would reflect an expectation of a change in the circumstances of the asset in the future, the impact of that expectation is reflected in market value. Examples of where the expectation of additional value being created or obtained in the future may have an impact on the market value include: the prospect of development where there is no current permission for that development...".

Significantly the recent publication of IVS 2017 seems to have fallen in line with both European Valuation Standards and the RICS Red book by adopting a more flexible interpretation of 'highest and best use' with these words:

"To reflect the requirement to be legally permissible, any legal restrictions on the use of the asset eg. zoning designations, need to be taken into account as well as the likelihood that these restrictions will change." And so it's seems that IVSC has finally recognised the concept of hope value without actually uttering those words. The internationally recognised standard setting bodies (IVSC, TEGoVA and RICS) should now focus on ensuring that there is no more confusion or misunderstanding about the interpretation of either "Highest and Best Use" or "Hope Value". Both concepts should now be taken into account when assessing Market Value.

\section{Evolution of the interpretation of market value in Poland}


The first professional standards were officially published in Poland in 1995 by the Polish Federation of Valuers 'Associations (PFVA). They were based on European Valuation Standards issued by TEGoVoFA (now TEGoVA) and the RICS Valuation Standards. The Polish standards were gradually updated and expanded in the course of development of the valuation profession in Poland. The Polish Statute on real property management of 21 August 1997 (Ustawa ... 1997) came into force only two years after the first publication of the professional standards.

At that time the Polish valuation standards were explicitly mentioned in the statute and they were legally binding.

In the above mentioned law, the definition of market value was stated as follows:

"The market value of a property is the expected price which can be obtained on the market, estimated having regard to transaction prices based on the following assumptions:

1. the parties to the transaction were independent, did not act under pressure and had a firm intention of concluding an agreement,

2. the time before the transaction was sufficient for the property to be exposed on the market and for the parties to negotiate the conditions of the agreement."

Subsequent amendments of the statute resulted only in the replacement of the words eht" expected price "with eht"most probable price". Academics drew attention to the contrast between the latter and the internationally accepted definition of market value which is seen as an "estimated amount" (KUCHARSKA-STASIAK 2010, GRZESIK, ŹRÓBEK 2012, KONOWALCZUK 2011). Still, the above-quoted Polish definition is still valid today. The statute on real property management also includes a provision concerning professional standards as follows: "Professional standards are established by professional organisations of property valuers in agreement with the minister responsible for construction, spatial development planning and housing" (Ustawa ... 1997). The freedom of valuers to shape valuation standards is also limited by the statutory definition of professional standards taken to mean, "the steps to be followed in undertaking property valuation in accordance with legal regulations". The definition of concepts even of fundamental importance in the valuation process have not been recognized as rules of procedure" The :provision meant that the previous standards lost their special legal status. They became no more than non binding guidance, as they had not been previously agreed upon with the relevant minister.

In the circumstances the PFVA decided to develop a new version of professional standards based on the latest editions of International (IVS) and European Valuation Standards (EVS). In response to the needs of local valuers, a standard titled "Market Value and Replacement Value", was developed by PFVA and published in 2008. The standard included an interpretation of the definition of "market value "based on the concept of "highest and best use", but adapted to fit the domestic, not yet fully matured, real estate market. However, the aim of full harmonisation with global and European standards suffered a setback because many Polish valuers did not accept the international interpretation of market value. In particular they rejected the assumption that fundamental to market value was the concept of the highest and best use of the property. A passionate discussion concerning the validity of taking into account of the highest and best use of the property in arriving at its market value raged in 2010 and 2011 amongst practitioners and academics alike (GRZESIK 2010; KALUS 2010; PRYSTUPA 2010). The proponents of the concept argued that property valuers tended to pay more attention to valuation methodology than to the underlying concepts of value which were little understood. They blamed the difficulties in defining and interpreting market value in Poland on the excessive trust in the legal regulation of value (KONOWALCZUK, RAMIAN 2013).

Publications explaining the "highest and best use elpicnirp "in a clear and simple way should have been the remedy for the fear and reluctance felt by property valuers in connection with the concept. They included interpretations of the concept of the "highest and best use "in the context of international norms and literature. The basic rules of analysing such use were also explained (e.g. ŹRÓBEK 2011). Nevertheless, property valuers were (and they still are) divided into those supporting the Anglo-Saxon approach and those who continued to perceive market value as merely the value of the current use of a property. As a result the attempt to introduce this concept of market value and turning it into a professional standard failed. The standard did not obtain the approval of the relevant minister. In 2013, the National Council of the PFVA passed a resolution to exclude the "Market Value and Replacement Value" standard from the General National Valuation Standards. Such lack of consistency was not conducive to building confidence in the valuation profession (GRZESIK, ŹRÓBEK 2012). 
The interpretation of market value, as set out in EVS 2012, and which indicated that the market value is intended to reflect the full potential of the property as perceived by the market, even if such potential (hope value) was not yet legally permissible at the date of valuation fell on deaf ears in some influential quarters. A survey in 2015 among Polish valuers, indicated that market value is determined in $88 \%$ of all valuations (ŹRÓBEK et al. 2016) but an analysis of literature and court judgements carried out in 2016, indicated a continuing lack of a uniform interpretation of market value, in particular on the question of the right choice between the assumption of existing use or the highest and best use of property in valuations. It can be said that current Polish valuation practice is a significant hindrance to the freedom of being guided by International and European Valuation Standards and even EU legislation.

One hopeful sign which may indicate a possible change in the perception of market value is the the PFVA's most recent attempt to develop a new professional standard, this time titled simply "Market Value". The draft of the latter is currently undergoing consultation amongst the Polish valuers 'community. However, given the current law, the draft provides two definitions and two interpretations of this value -one with a reference to the hope value and one without such a reference.

The understanding of the concept of the value feels "forced "in the context of creating provisions of Polish law. The government has prepared a draft version of a correction of the legal definition of the market value as set out in the statute on real property management, in order to harmonise its wording with the definition formulated in the EU Regulation (CRR 2013).

Fortunately, as usually happens in such situations, members of academia and professional organisations have taken action and started to "suggest "to property valuers and the government, various ways in which such assumptions could be implemented, for example, in relation to determining the compensation in the case of property expropriation (YEUNG 2014). Konowalczuk and Ramian believe also that the concept of "hope value "has an advantage over "highest and best use", because thevery name draws investors' attention to the need to identify specific risks associated with investing in a particular piece of real estate (KONOWALCZUK, RAMIAN 2013). In their opinion, it is not unimportant that such a simple term would be used to refer to many complex situations occurring in valuation practice and related to the potential growth of the real property market value.

\section{Additional remarks}

The broad scope of legal regulations affecting the Polish valuation profession has had a significant impact on the form and content of valuation standards and the speed and extent of harmonisation with European and international standards. Such regulations impact the assumptions which valuers make concerning the use of a property as at the date of valuation. In this respect, the local Master Plan is key in determining what assumptions concerning the use of a property can be made. If there is no such Master Plan, the potential use of a property is determined on the basis of a lesser planning document known as a "study of conditions for development and land use". Only if these planning documents are missing does one reflect the actual use of the property.

On the other hand, the Supreme Court has taken the following position on the issue: The designation of property is the same as its intended use. On the other hand, the use of real property means a specific way, manner or mode of performing an agreement. The use of real property must therefore, in principle, correspond to the designation of the property. It follows from the above that the concepts of the noitangised" of real property" and the "use of property "remain in close relationship to one another (Wyrok ... 2011).

The provisions of the Building Code on the freedom to change the designation of a building are an additional factor (Prawo ... 2006). These are, therefore, strong regulations which should be taken into account when considering different uses of the property being valued which are different to the existing use.

It is also worth noting that perception of land and property is determined also by factors other than economic ones. Emotional perceptions of land can differ greatly from an economic perception. The highest and best use of property may be a result of individual assessment which can be influenced by social, economic, environmental and historic awareness, as well as emotional attachment to a given place, the identity of the place or non-material factors (SZCZEPAŃSKA 2012). This is an important issue to consider because quite often such assessment will differ from the idea of the highest and best use resulting from an analysis of the market. Therefore, in the light of the need for more sustainable development and greater ecological awareness among societies, one should "weigh "the superiority of economic optimisation over preservation of the environment very carefully. 


\section{Conclusions and recommendations}

A detailed analysis of the concept of market value as defined in International and European Valuation Standards and the evolution of views in Poland leads us to the following conclusions and recommendations:

1. It should be noted that "hope value "indicates much more strongly than the "highest and best use "principle that the determined market value involves more uncertainty as to how long a use will remain unchanged.

2. The concept of "hope value "should be introduced to the Polish professional standards as a further extension of the "highest and best use "principle which was included in the $2016 \mathrm{draft}$ of the "Market Value "standard.

3. There is a need to change the definition of "professional standard" as set out in the statute on land management, as the current definition does not allow for agreement with the relevant minister on such a key matter for property valuation as the interpretation of market value.

4. There is therefore a need to intensify research on determining the probability of a use assumed for valuation becoming reality and its influence on the determined value. Additionally, it seems necessary to intensify efforts devoted to measuring the risk of investing in property, considering that decisions made on the basis of a market value which reflects "hope value "can involve a higher level of risk.

5. For its part TEGoVA should consider whether additional guidance should be included in future editions of European Valuation Standards on how to arrive at the "hope value" element of market value.

\section{References}

CRR, Capital Requirements Regulation 575/2013/EU.

EVS, European Valuation Standards 2016 (TEGoVA).

Finch H. J., CASAVANT R., 1996, Highest and Best Use and the Special Purpose Property, The Appraisal Journal, vol 64, no 2, ISSN: 0003-7087.

GRZESIK K., 2010, Europejska szkoła wyceny (The European School of Valuation), Rzeczoznawca Majątkowy, PFSRM Warszawa, no 4 (68), pp.18-19.

GRZESIK K., 2014a, Internationally Recognised Valuation Standards - Differences in Interpretation of Market Value, Journal of the Recognised European Valuer (REV Journal), 2014, no 7, pp.3, access data: 23.03.2017, http://www.tegova.org/data/bin/a56efb61d24f27_Journal\%20of\%20the\%20 Recognised \%20Valuer\%20(7)\%20May\%202014.pdf.

GRZESIK K., 2014b, Equal Bedfellows in Developing Valuation Standards - The Institute of Revenues Rating and Valuation (IRRV), Jan 2014,

GRZESIK K., ŹRÓBEK S., 2012, Nowe europejskie interpretacje wartości rynkowej i godziwej (New European Interpretations of Market Value And Fair Value) Studia i Materiały Towarzystwa Naukowego Nieruchomości, vol. 20, no. 2, pp. 97-104.

http://hk-lawyer.org/sites/default/files/field/journal/201402_HK_Lawyer.pdf.

IVS, International Valuation Standards 2017, ed. by International Valuation Standards Council (IVSC).

KALUS S., 2010, Konstruowanie pojęcia wartości rynkowej nieruchomości w kontekście odpowiedzialności rzeczoznawcy majatkowego (Determining the concept of market value of property in the light of the valuers' reponsibilities), Rzeczoznawca Majątkowy, nr 4 (68), pp.7-14.

KONOWALCZUK J., 2011, Standaryzacja wyceny nieruchomości w Polsce (The standardisation of property valuation in Poland), Świat Nieruchomości, no 2 (76), pp. 4-11.

KONOWALCZUK J., RAMIAN T., 2013, Ocena warunków i możliwości wykorzystania koncepcji hope value do określania wartości rynkowej nieruchomości przedsiębiorstw w Polsce (Evaluation of the conditions and opportunities of employing the concept of "hope value" for determining the market value of corporate real estate in Poland), Zeszyty Naukowe Uniwersytetu Szczecińskiego, no 761, pp. 70-80.

KuCHARSKA-STASIAK E., 2010, Powrót do źródet - dyskusja wokót wartości rynkowej (Return to origins discussion concerning market value), Rzeczoznawca Majątkowy, vol. 67, pp. 16-22.

KuCharSKa-Stasiak E., ŹróBeK S., 2015, An Attempt to Exemplify the Economic Principles in Real Property Valuation, Real Estate Management and Valuation, vol. 23, no. 3, pp. 5-13.

LENNHOFF D.C., ElgIE W.A. III, 1995, Highest and Best User, The Appraisal Journal, vol. 63, no 3, ISSN: 0003-7087. 
Prawo budowlane 2006 (Building Code) (tekst jedn. Dz.U. z 2006 r. Nr 156, poz. 1118 ze zm. - access data: 23.03.2017.

PRYSTUPA M., 2010, Polska szkoła wyceny (The Polish school of valuation), Rzeczoznawca Majątkowy, no 3 (67), pp. 22-27.

RATTERMANN M. R., MAI, SRA, 2014, The Student Handbook to The Appraisal of Real Estate, 14th Edition, Appraisal Institute, W.Van Buren, Chicago, IL, ISBN: 978-1-935328-50-6.

RICS Professional - Valuation Standards 2014.

SCRIBNER D. JR, 1997, A new standard for conducting highest and best studies of income-producing properties in the USA and the UK, Journal of Property Valuation \& Investment, MCB University Press, vol. 15, no 5, pp. 466-478.

SZCZEPAŃSKA A., 2012, Niematerialne czynniki kształtujące indywidualne pojecie optymalnego sposobu użytkowania nieruchomości (Intangible factors that ahape an individual approach to the optima use of real estates), Studia i Materiały Towarzystwa Naukowego Nieruchomości, vol. 20, no 2, pp. 167-175.

The appraisal of real estate. 2013. Appraisal Institute.14th ed. Chicago, Illinois, USA. pp. 847.

Ustawa z dnia 21 sierpnia 1997 r. o gospodarce nieruchomościami, Dz.U.1997 nr 15 poz 741 z póź. zm. (The Act on real property management of 21 August 1997) - access data: 23.03.2017.

Wyrok Sądu Najwyższego z dnia 28 stycznia 2011 r. (Judgement of Suprime Court 2011), I CSK 132/10, LEX nr 848104.

YeunG C., 2014, Hope Value, Hong Kong Lawyer: The official journal of the law society of Hong Kong. no February 2014, pp. 32-40.

ŹRÓBEK S., 2011, Sposób optymalnego użytkowania nieruchomości - ujecie definicyjne i metodyczne (The Highest and Best use of real estate - definition and methodological approach), Studia i Materiały Towarzystwa Naukowego Nieruchomości, vol. 19, no 1, pp. 19-26.

ŹRÓBEK S., KUCHARSKA-STASIAK E., NAIMAVICIENE J., TUPENAITE L., 2016, Selected aspects of real estate appraisers' professional training on the background of economic theory, Journal of International Studies, vol. 9, no 2, pp. 251-258. 